\title{
Synthesis of Magnesium Oxide Nanopowder by Thermal Plasma Using Magnesium Nitrate Hexahydrate
}

\author{
V. Sirota, ${ }^{1}$ V. Selemenev, ${ }^{2}$ M. Kovaleva, ${ }^{3}$ I. Pavlenko, ${ }^{1}$ K. Mamunin, ${ }^{1}$ \\ V. Dokalov, ${ }^{1}$ and M. Prozorova ${ }^{3}$ \\ ${ }^{1}$ Center for Constructional Ceramics and the Engineering Prototyping, Belgorod National Research University, \\ Pobedy 85, Belgorod 308015, Russia \\ ${ }^{2}$ Voronezh State University, Universitetskaya Plóshchad' 1, Voronezh 394006, Russia \\ ${ }^{3}$ Joint Research Center, Belgorod National Research University, Pobedy 85, Belgorod 308015, Russia
}

Correspondence should be addressed to V. Sirota; sirota@bsu.edu.ru

Received 29 October 2015; Accepted 26 January 2016

Academic Editor: Ali Hussain Reshak

Copyright (C) 2016 V. Sirota et al. This is an open access article distributed under the Creative Commons Attribution License, which permits unrestricted use, distribution, and reproduction in any medium, provided the original work is properly cited.

\begin{abstract}
Magnesium oxide $(\mathrm{MgO})$ nanopowder was synthesized by thermal plasma in a novel thermal DC plasma torch using magnesium nitrate hexahydrate. Magnesium nitrate hexahydrate $\left(\mathrm{Mg}\left(\mathrm{NO}_{3}\right)_{2} \cdot 6 \mathrm{H}_{2} \mathrm{O}\right)$ was obtained from serpentinite $\left(\mathrm{Mg}_{3} \mathrm{Si}_{2} \mathrm{O}_{5}(\mathrm{OH})_{4}\right.$; lizardite) (Halilovskiy array, Orenburg region, Russia). The synthesized samples were characterized by analytical techniques including X-ray diffraction (XRD) and transmission electron microscopy (TEM). XRD and TEM characterization studies confirmed that $\mathrm{MgO}$ nanopowder obtained has periclase structure with high purity, and the particle sizes vary within the range of $100 \mathrm{~nm}$ to $150 \mathrm{~nm}$. We believe that the present work will promote further experimental studies on the physical properties and the applications of $\mathrm{MgO}$ nanopowders in the fields such as high-densed ceramics, additives in bactericide, and refractory products.
\end{abstract}

\section{Introduction}

Magnesium oxide $(\mathrm{MgO})$ is an attractive material which has many potential applications, such as water purification, optoelectronics, and microelectronics, is an additive in heavy fuel oil, paint, gas separation, and bactericides, and is an insulator in industrial cables, crucibles, and refractory materials. However, the useful properties of $\mathrm{MgO}$ are further enhanced when used as nanosized powder with novel nanostructures [1-4]. Many methods like flame spray pyrolysis [5], combustion aerosol synthesis [6], hydrothermal method [7], laser vaporization [8], chemical gas phase deposition [9], solvothermal method [10], aqueous wet chemical method [11], and others [12-14] have been developed for the synthesis of nanosize of $\mathrm{MgO}$.

Among the different techniques commonly used for preparation of magnesium oxide, thermal plasmas which provide high temperatures and steep temperature gradients offer an attractive and chemically unspecific route for synthesizing fine refractory powders [15-18]. Thermal plasmas suitable for synthesis are primarily produced by means of high intensity AC or DC arcs, high frequency discharges, DC-RF hybrid plasmas, and a reactive submerged arc (RSA). Depending on the process, either the discharge itself or the plasma flame downstream of the discharge may be used for synthesizing the powders. In thermal plasma synthesis, the reactants may be gases, liquids, or solids before injection into the plasma [19].

In this paper, we report the synthesis and characterization of magnesium oxide nanopowder by thermal plasma in a novel thermal DC plasma torch using magnesium nitrate hexahydrate as the precursor.

\section{Experimental Procedure}

Magnesium nitrate hexahydrate $\left(\mathrm{Mg}\left(\mathrm{NO}_{3}\right)_{2} \cdot 6 \mathrm{H}_{2} \mathrm{O}\right)$ was obtained from serpentinite (Halilovskiy array, Orenburg region, Russia). Serpentinite consisted mostly of magnesium, silicon, and iron in the form of serpentinite $\left(\mathrm{Mg}_{3} \mathrm{Si}_{2} \mathrm{O}_{5}(\mathrm{OH})_{4}\right.$; lizardite). 


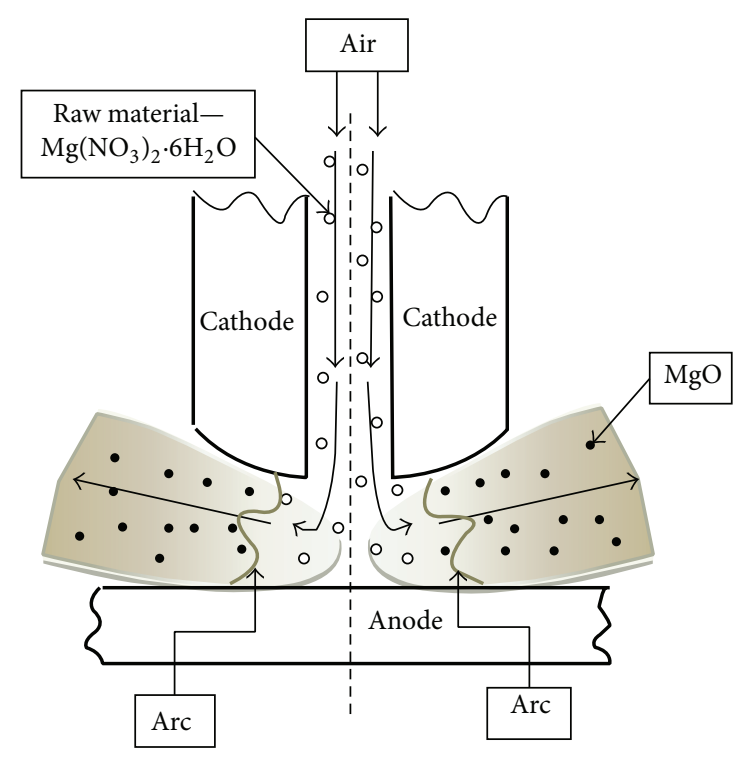

FIGURE 1: Schematic diagram of a novel thermal DC plasma torch.

Serpentinite was dissolved in $40 \%$ nitric acid solution. $\mathrm{MgNO}_{3}$ solution was obtained after the ions like $\mathrm{Fe}^{3+}$ and $\mathrm{Fe}^{2+}$ were transformed into hydroxide precipitates, and the precipitates were separated by filtration. $\mathrm{MgNO}_{3}$-rich solution was transferred to a glass beaker for evaporation of the solution. The solution started boiling at $90^{\circ} \mathrm{C}$ and was boiled for $4 \mathrm{~h}$ in order to evaporate most of the solvent. The residue of hydrated magnesium carbonate was cooled to room temperature and filtered. $\mathrm{Mg}\left(\mathrm{NO}_{3}\right)_{2} \cdot 6 \mathrm{H}_{2} \mathrm{O}$ was ground by a vortex jet flow type mill (productivity of $50 \mathrm{~g}$ per minute, air pressure of $10 \mathrm{bar}$, and air volume of $1 \mathrm{~m}^{3} / \mathrm{min}$ ).

$\mathrm{MgO}$ nanopowder was synthesized by using thermal plasma from magnesium nitrate hexahydrate $\left(\mathrm{Mg}\left(\mathrm{NO}_{3}\right)_{2}\right.$. $\left.6 \mathrm{H}_{2} \mathrm{O}\right) \cdot \mathrm{Mg}\left(\mathrm{NO}_{3}\right)_{2} \cdot 6 \mathrm{H}_{2} \mathrm{O}$ was easily decomposed in the high temperature (T) range of plasma and converted to $\mathrm{MgO}$ particle due to rapid quenching:

$$
2 \mathrm{Mg}\left(\mathrm{NO}_{3}\right)_{2} \stackrel{\mathrm{T}^{\circ} \mathrm{C}}{\rightarrow} 2 \mathrm{MgO}+4 \mathrm{NO}_{2} \uparrow+\mathrm{O}_{2} \uparrow
$$

A novel thermal DC plasma torch has been employed for the production of $\mathrm{MgO}$ nanopowder (Figure 1). The powder is separated during the passage of the gas-dust mixture through a system of cyclones, and the gas mixture is utilized in the venturi scrubber.

The phase composition of the samples was analyzed by Xray diffraction (XRD) with $\mathrm{CuK} \alpha$ radiation. A Rigaku Ultima IV X-ray powder diffractometer was used. Crystalline phases were identified by the ICDD PDF-2 (2008) powder diffraction database. The microstructure of $\mathrm{MgO}$ nanopowder was carried out using a JEM 2100 (JEOL Ltd., Tokyo, Japan) transmission electron microscope (TEM) equipped with an INCA energy-dispersive X-ray spectrometer (EDS; Oxford Instruments, Oxfordshire, UK) with an acceleration voltage of $200 \mathrm{kV}$. The TEM specimens are prepared by method for the preparation of micrometer-sized powder particles described in [20].
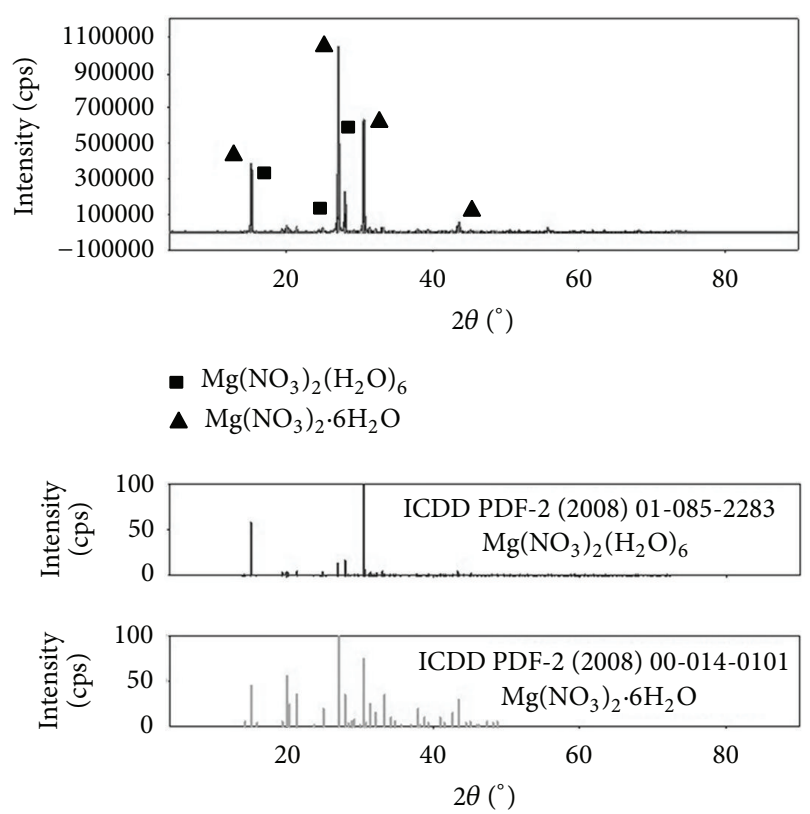

FIGURE 2: XRD pattern for $\mathrm{Mg}\left(\mathrm{NO}_{3}\right)_{2} \cdot 6 \mathrm{H}_{2} \mathrm{O}$ produced from serpentinite.

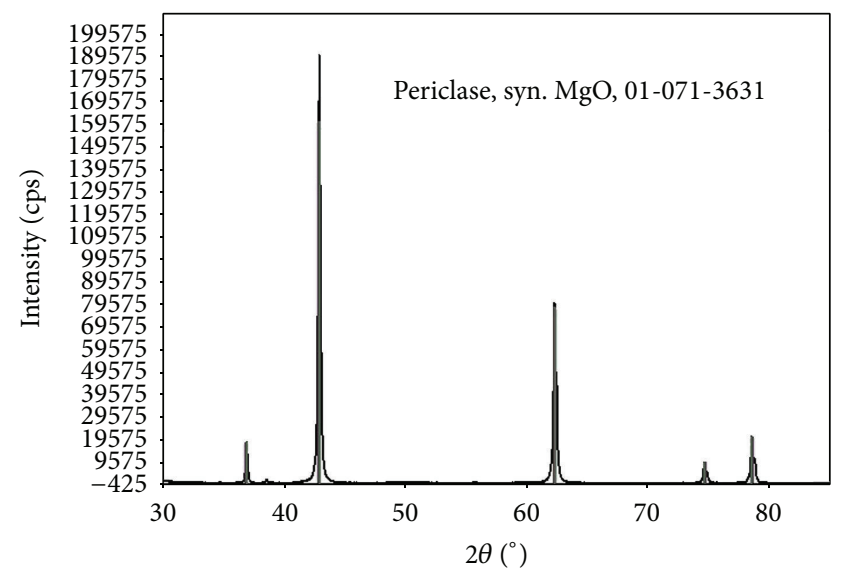

Figure 3: XRD pattern for MgO nanopowder.

\section{Results and Discussion}

Analysis of the phase composition of the magnesium nitrate $\left(\mathrm{Mg}\left(\mathrm{NO}_{3}\right)_{2} \cdot 6 \mathrm{H}_{2} \mathrm{O}\right)$ shows that, according to the ICDD data catalog (Figure 2), the powder consists of $\mathrm{Mg}\left(\mathrm{NO}_{3}\right)_{2}\left(\mathrm{H}_{2} \mathrm{O}\right)_{6}$ with a monoclinic lattice with $\mathrm{P} 121 / \mathrm{cl}$, unique-b, cell-1 space group and $\mathrm{Mg}\left(\mathrm{NO}_{3}\right)_{2} \cdot 6 \mathrm{H}_{2} \mathrm{O}$ with a monoclinic lattice with $\mathrm{P} 121 / c 1$, unique-b, cell-1 space group phases.

The key idea in this study is to prepare the nanosized $\mathrm{MgO}$ particles with high crystallinity and no impurities.

Analysis of the phase composition of $\mathrm{MgO}$ nanopowder (Figure 3) shows that, according to the ICDD data catalog, it is one-phase material $\mathrm{MgO}$ (periclase) and had cubic lattice with Fm-3m space group ( $a=b=c=4.215 \AA$ ). No diffraction peaks representing other phases were detected in Figure 2, which indicated high purity of the periclase. 


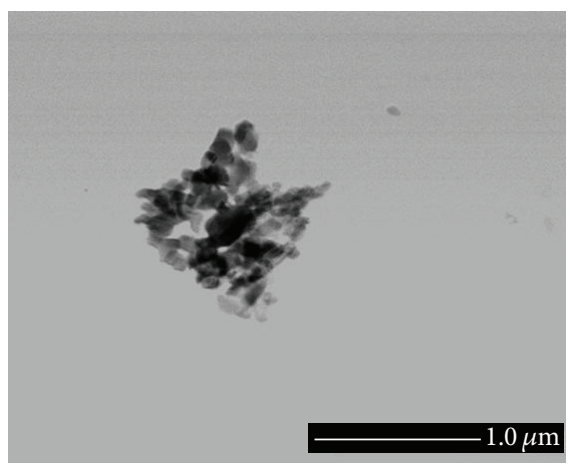

(a)

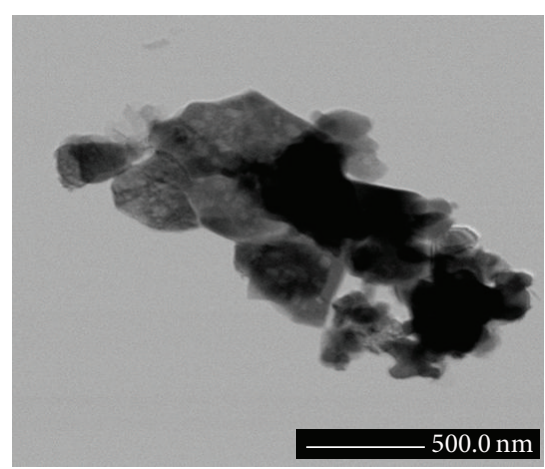

(b)

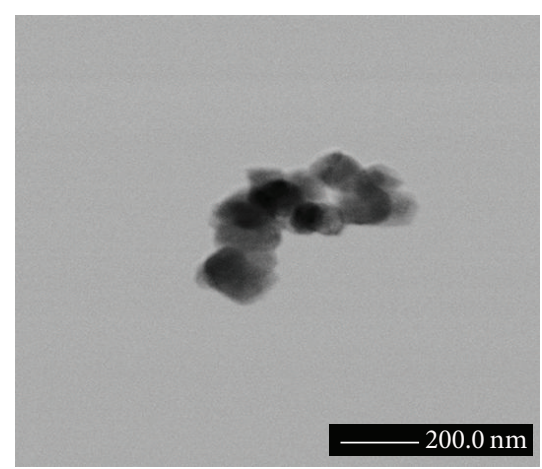

(c)

Figure 4: TEM image of MgO nanoparticles for different magnification: (a) $60 \mathrm{~K}$ and (b, c) $100 \mathrm{~K}$.

This present value is in good accordance with the literature reports. All reflections are sharp with slight broadening. These reflect the crystalline nature of $\mathrm{MgO}$ nanopowder.

Transmission electron microscope (TEM), a powerful method for structure analysis at a nanometer scale, allows for direct observation of the morphological and structural features of $\mathrm{MgO}$ samples. The morphological and structural features of $\mathrm{MgO}$ nanopowder, shown in Figure 4, were characterized with transmission electron microscope (TEM). The TEM images are shown in different magnifications. These images illustrate that small amount of agglomeration is present in the sample. The results showed that $\mathrm{MgO}$ nanopowder with irregular morphology with size in the range of $100-150 \mathrm{~nm}$ was fabricated.

\section{Conclusions}

From our present work, it is concluded that it is easy to prepare $\mathrm{MgO}$ nanoparticles by thermal plasma in a novel thermal DC plasma torch using magnesium nitrate $\left(\mathrm{Mg}\left(\mathrm{NO}_{3}\right)_{2}\right.$. $\left.6 \mathrm{H}_{2} \mathrm{O}\right)$ as precursor. The XRD patterns show that the obtained magnesium oxide $(\mathrm{MgO})$ nanopowder has the periclase structure. The XRD pattern confirmed the crystallinity and phase purity of the nano-MgO powder. $\mathrm{MgO}$ powder has very homogeneous structure without any observable pores. $\mathrm{MgO}$ materials obtained by thermal plasma using magnesium nitrate $\left(\mathrm{Mg}\left(\mathrm{NO}_{3}\right)_{2} \cdot 6 \mathrm{H}_{2} \mathrm{O}\right)$ as precursor may prove potential applications in catalyst, water purification, pigments, optoelectronics, bactericides, insulator, crucibles, substrate, and refractory materials.

\section{Conflict of Interests}

The authors declare that there is no conflict of interests regarding the publication of this paper.

\section{Acknowledgments}

Applied research is carried out with financial support from the state on behalf of the Ministry of Education and Science of the Russian Federation of the Agreement no. 14.577.21.0111 (22 September 2014). The unique identifier of the applied research is RFMEFI57714X0111. All of the studies were carried out on the equipment of the Joint Research Center of Belgorod State National Research University "Diagnostics of structure and properties of nanomaterials."

\section{References}

[1] B. Nagappa and G. T. Chandrappa, "Mesoporous nanocrystalline magnesium oxide for environmental remediation," Microporous and Mesoporous Materials, vol. 106, no. 1-3, pp. 212-218, 2007.

[2] K. V. Rao and C. S. Sunandana, "Structure and microstructure of combustion synthesized $\mathrm{MgO}$ nanoparticles and nanocrystalline $\mathrm{MgO}$ thin films synthesized by solution growth route," Journal of Materials Science, vol. 43, no. 1, pp. 146-154, 2008.

[3] N. C. S. Selvam, R. T. Kumar, L. J. Kennedy, and J. J. Vijaya, "Comparative study of microwave and conventional methods for the preparation and optical properties of novel $\mathrm{MgO}$-micro and nano-structures," Journal of Alloys and Compounds, vol. 509, no. 41, pp. 9809-9815, 2011.

[4] Z. Camtakan, S. Erenturk, and S. Yusan, "Magnesium oxide nanoparticles: preparation, characterization, and uranium sorption properties," Environmental Progress and Sustainable Energy, vol. 31, no. 4, pp. 536-543, 2012.

[5] L. Mädler, H. K. Kammler, R. Mueller, and S. E. Pratsinis, "Controlled synthesis of nanostructured particles by flame spray pyrolysis," Journal of Aerosol Science, vol. 33, no. 2, pp. 369-389, 2002.

[6] B.-Q. Xu, J.-M. Wei, H.-Y. Wang, K.-Q. Sun, and Q.-M. Zhu, "Nano-MgO: novel preparation and application as support of Ni catalyst for $\mathrm{CO}_{2}$ reforming of methane," Catalysis Today, vol. 68, no. 1-3, pp. 217-225, 2001.

[7] B. Zheng, C. Lu, G. Gu, A. Makarovski, G. Finkelstein, and J. Liu, "Efficient CVD growth of single-walled carbon nanotubes on surfaces using carbon monoxide precursor," Nano Letters, vol. 2, no. 8, pp. 895-898, 2002.

[8] G. W. Wagner, P. W. Bartram, O. Koper, and K. J. Klabunde, "Reactions of VX, GD, and HD with nanosize MgO," Journal of Physical Chemistry B, vol. 103, no. 16, pp. 3225-3228, 1999.

[9] Y. Hao, G. Meng, C. Ye, X. Zhang, and L. Zhang, "Kineticsdriven growth of orthogonally branched single-crystalline magnesium oxide nanostructures," Journal of Physical Chemistry B, vol. 109, no. 22, pp. 11204-11208, 2005. 
[10] Z. Zhao, H. Dai, Y. Du, J. Deng, L. Zhang, and F. Shi, "Solvo- or hydrothermal fabrication and excellent carbon dioxide adsorption behaviors of magnesium oxides with multiple morphologies and porous structures," Materials Chemistry and Physics, vol. 128, no. 3, pp. 348-356, 2011.

[11] A. Bhargava, J. A. Alarco, I. D. R. Mackinnon, D. Page, and A. Ilyushechkin, "Synthesis and characterisation of nanoscale magnesium oxide powders and their application in thick films of $\mathrm{Bi}_{2} \mathrm{Sr}_{2} \mathrm{CaCu}_{2} \mathrm{O}_{8}$," Materials Letters, vol. 34, no. 3-6, pp. 133142, 1998.

[12] K. Kaviyarasu and P. A. Devarajan, "A versatile route to synthesize MgO nanocrystals by combustion technique," Der Pharma Chemica, vol. 3, no. 5, pp. 248-254, 2011.

[13] S. Makhluf, R. Dror, Y. Nitzan, Y. Abramovich, R. Jelinek, and A. Gedanken, "Microwave-assisted synthesis of nanocrystalline $\mathrm{MgO}$ and its use as a bacteriocide," Advanced Functional Materials, vol. 15, no. 10, pp. 1708-1715, 2005.

[14] M. A. Shah, "Preparation of $\mathrm{MgO}$ nanoparticles with water," African Physical Review, vol. 21, no. 4, pp. 21-23, 2010.

[15] F. Meshkani and M. Rezaei, "Facile synthesis of nanocrystalline magnesium oxide with high surface area," Powder Technology, vol. 196, no. 1, pp. 85-88, 2009.

[16] P. Ouraipryvan, T. Sreethawong, and S. Chavadej, "Synthesis of crystalline $\mathrm{MgO}$ nanoparticle with mesoporous-assembled structure via a surfactant-modified sol-gel process," Materials Letters, vol. 63, no. 21, pp. 1862-1865, 2009.

[17] J.-H. Seo and B.-G. Hong, "Thermal plasma synthesis of nanosized powders," Nuclear Engineering and Technology, vol. 44, no. 1, pp. 9-20, 2012.

[18] G. Vissokov, I. Grancharov, and T. Tsvetanov, "On the plasmachemical synthesis of nanopowders," Plasma Science and Technology, vol. 5, no. 6, pp. 2039-2050, 2003.

[19] C. K. Peter and Y. C. Lau, "Plasma synthesis of ceramic powders," Pure and Applied Chemistry, vol. 62, no. 9, pp. 1809-1816, 1990.

[20] D. V. Sridhara Rao, K. Muraleedharan, and C. J. Humphreys, "TEM specimen preparation techniques," in Microscopy: Science, Technology, Applications and Education, A. Méndez-Vilas and J. Díaz, Eds., pp. 1232-1244, Formatex Research Center, Badajoz, Spain, 2010. 

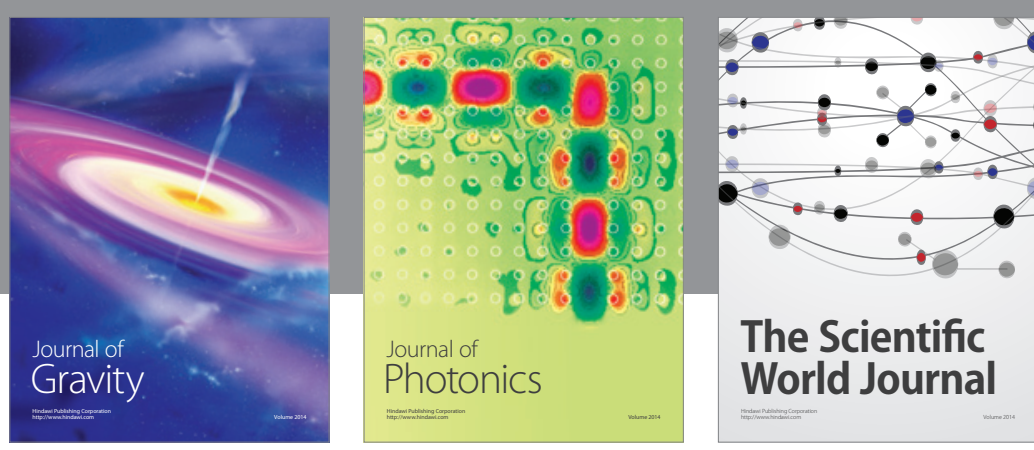

The Scientific World Journal
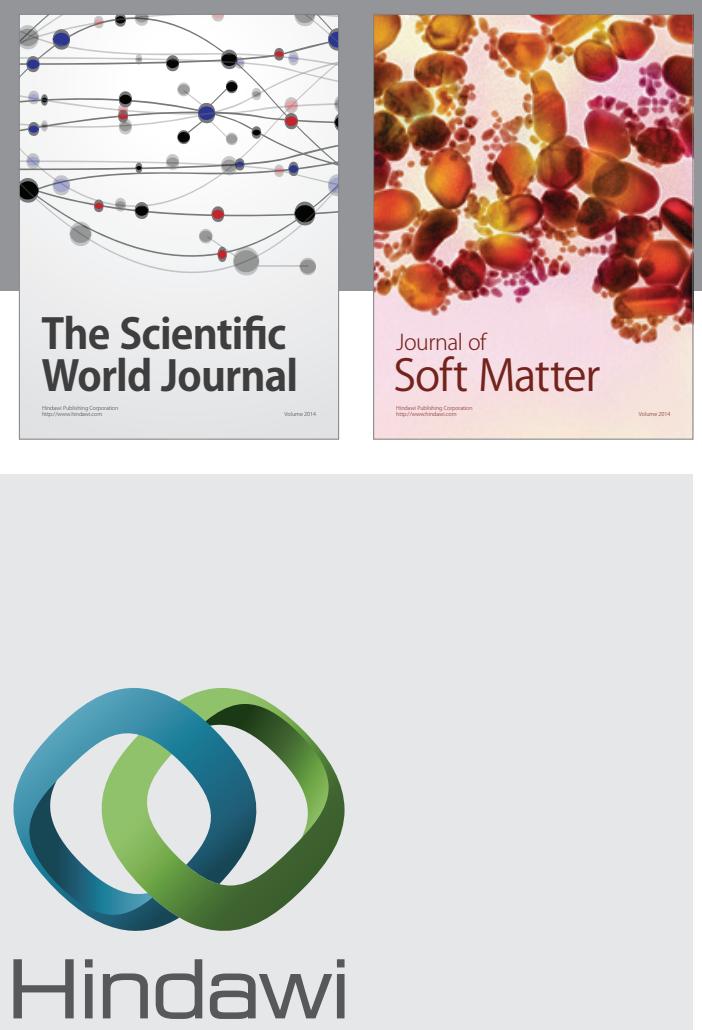

Submit your manuscripts at

http://www.hindawi.com

nternational Journal of

Statistical Mechanics
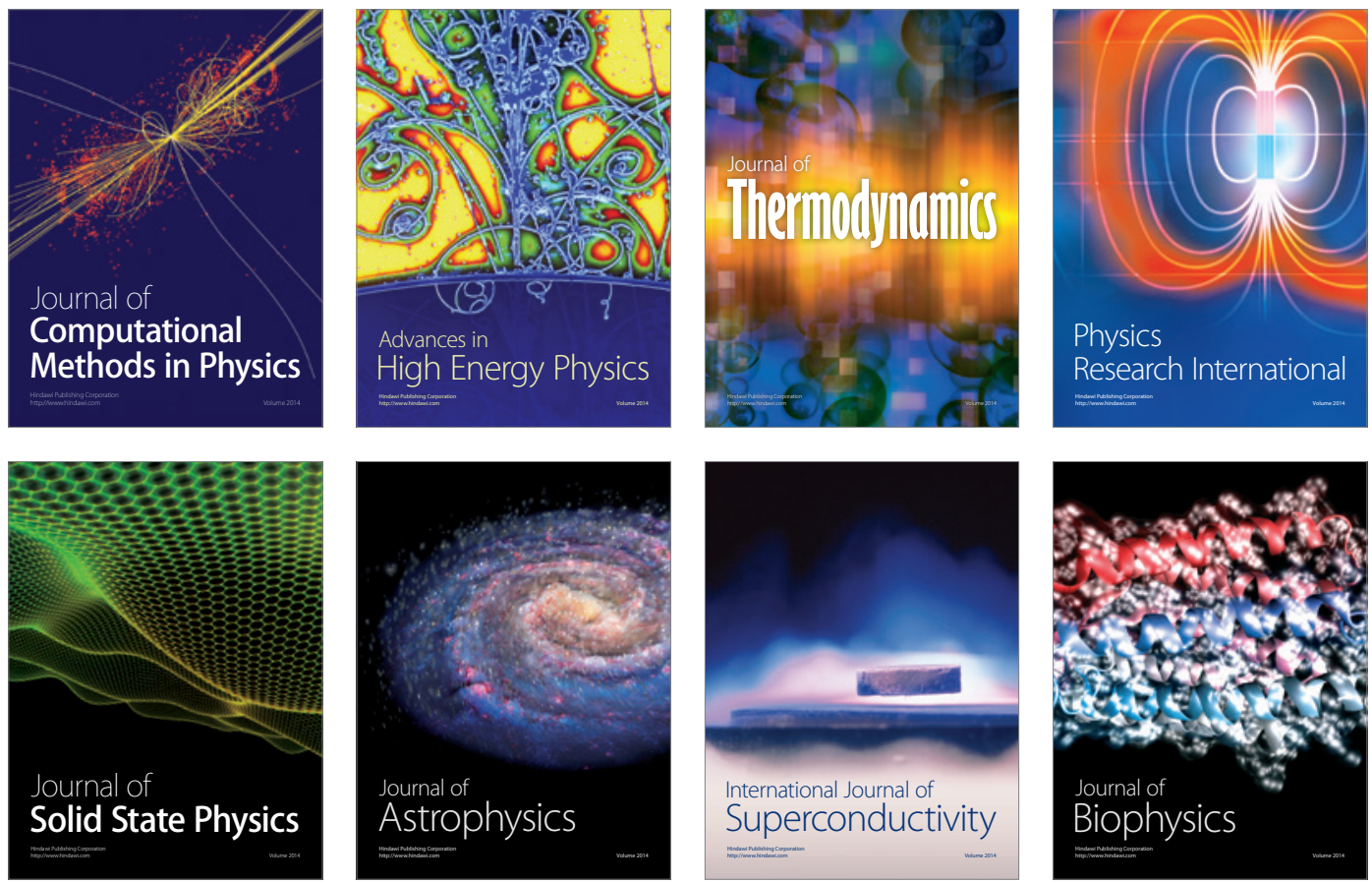
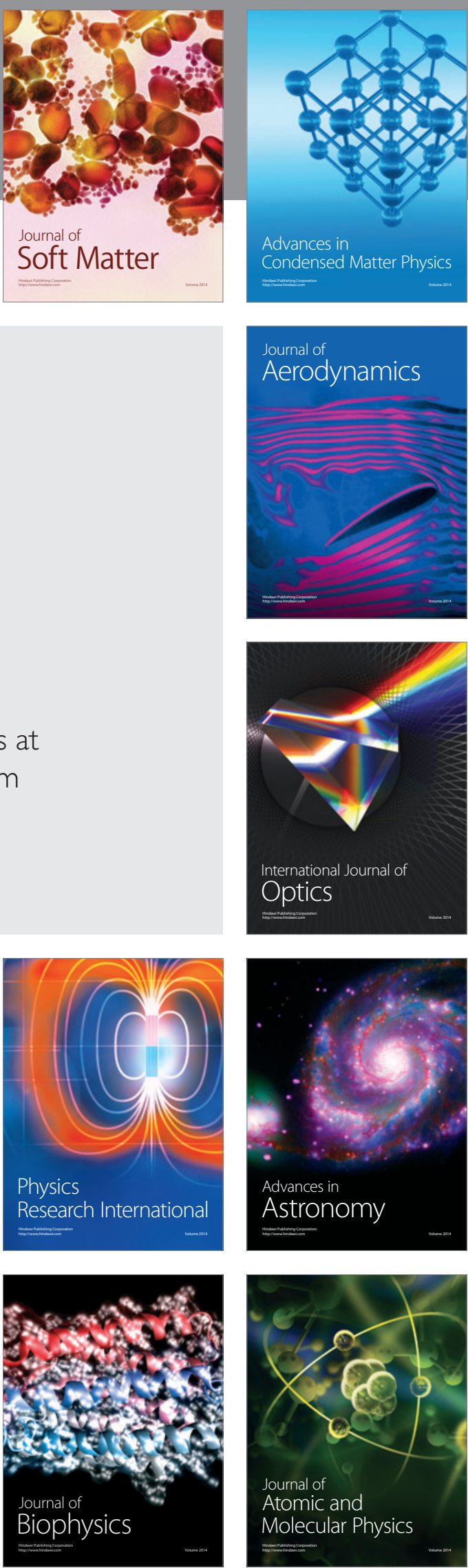